\title{
Written Grammatical Errors of Arabic as Second Language (ASL) Learners: An Evaluative Study
}

\author{
Sadeq Ali Saad Al-Yaari (Corresponding author) \\ Independent Researcher, Dept. of English, College of Arts, King Saud University (KSU) \\ Riyadh, Kingdom of Saudi Arabia. E-mail: prof.sadeq@gmail.com
}

Fayza Saleh Al Hammadi

Associate prof., Dept. of English, College of Arts, King Faisal University, Al-Hassa

Kingdom of Saudi Arabia. E-mail: viceii.library@kfu.edu.sa

\begin{abstract}
Salah Ayied Alyami
Assistant professor, Dept. of English, Dammam College of Technology, Dammam University Riyadh, Kingdom of Saudi Arabia. E-mail: salah1sa@yahoo.com
\end{abstract}

Received: January 1, 2013 Accepted: January 10, 2013 Published: January 17, 2013

doi:10.5296/ijele.v1i2.3063 URL: http://dx.doi.org/10.5296/ijele.v1i2.3063

\begin{abstract}
Background: In recent years, the number of non-native speakers of Arabic language has exponentially increased.

Aims: This analytical study aims at investigating written grammatical errors committed by Arabic as second Language (ASL) learners. More specifically, it explores the reasons behind committing these errors and their effects on the daily communication of ASL learners.

Methods: Ten (10) ASL senior learners of Arabic Language Institute (ALI), College of Arts, King Saud University (KSU), Riyadh, Kingdom of Saudi Arabia (KSA) were randomly selected in this study. The participants were asked to write paragraphs about themselves and then their written work was linguistically analyzed and evaluated by the researchers and some Arabic Language experts before it was statistically analyzed.
\end{abstract}

Conclusions: Results outline that written grammatical errors of ASL learners are characterized by the misuse of many grammatical items. Mainly these items are: proper 


\section{Macrothink}

International Journal of English Language Education ISSN 2325-0887 2013, Vol. 1, No. 2, Special Issue

nouns (PN), common nouns (CN), main verbs (MV), adjectives (adj.), time adverbs (T. Adv.), manner adverbs (M. Adv.), objective pronouns (OP), and central determiners (C Det.) including demonstratives (Dem.) and articles (Artic.), pronouns (Pron.) and prepositions (Prep.).

Keywords: Written, Grammatical errors, Arabic, Second Language, non-native Learners, Analysis 


\section{Introduction}

Over the past few decades, some Arab universities have witnessed exponential growth in the numbers of Arabic as Second Language (ASL) learners who enter their programs, creating a need for more specialized approaches in Arabic composition programs. During this time, Arabic writing theorists were busy developing approaches to writing instruction. Some of these approaches left grammar correction until later drafts in the writing process. Arabic grammarians at all levels reported success using this method, but not Arabic instructors as they were fond of approaches which were less troublesome for ASL learners who often felt inferior because of their non-standard written Arabic. Observing frequent written grammatical errors committed by ASL learners, Arabic teachers started to apply the process of new approaches in teaching grammar to ASL learners. Clearly, new methodologies and designs were needed to help these ASL learners to write correct grammatical writing about different types of topics. Practically, Arab linguists made it clear that most (if not all) ASL learners need continuous assistance with intensive programs to develop their writing skills for years even when they become fluent speakers of Arabic (ibn Jinnī, 1972).

Some linguists suggested presenting Arabic grammar in a modern way that is different from the classical one. According to these linguists, this does not mean changing the fundamental rules of traditional Arabic grammar which make people hate it. Conversely, shifting Arabic grammar from the current situation into another simplified way is supposed to be a constructive, not destructive. In other words, it is supposed to create winners more than losers (al-Anșārī, 1979) However, this study tries to diagnose the problems related to written grammatical work of some of these ASL learners. It aims at making crucial suggestions and solutions to these learners which will help other second language learners (SLL) to get benefit from its results.

In summary, this study aims at providing a new approach in solving the phenomenon under the question based on the scientific analyses it follows, correct alternatives it gives, and effective treatments it recommends. It aims at diagnosing the grammatical errors made by ASL learners in their everyday writing, recognizing them, and analyzing them in terms of how and why these ASL learners commit them, and suggesting ways to avoid them. Based on the outcome of this study, the researchers hope to contribute towards changing the present methods/ approaches used for teaching Arabic grammar at Arabic as Second/ Foreign Language (AS/FL) institutions particularly.

\subsection{Objectives of the Study}

This study attempts to find answers to the following questions:

1. What are the common written grammatical errors made by ASL learners both in major word classes and minor word classes?

2. How and why these ASL learners commit them? To what extent these errors become serious? 
3. How can ASL learners avoid committing such mistakes before they become errors?

\subsection{Method}

The analysis of ASL learners' written work errors was done in several steps: The researchers started by collecting data. Having completed data collection, they asked the participants (P) to write paragraphs about themselves. As clinically elicited data, it was expected to find these ASL learners focus on the content/ message rather than on the form i.e. meaningful writing (what they meant by what they wrote), not mechanical one (writing for practice no matter what the content is).

The study used a set of ten samples of written work done by 10 ASL senior learners study at Arabic Language Institute (ALI), College of Arts, King Saud University (KSU). The distribution of the participants is as follows: (P.1, 27 years old, Albania), (P.2, 27 years old, Ghana), (P.3, 31 years old, Ethiopia), (P.4, 22 years old, Somalia), (P.5, 26 years old, China), (P.6, 19 years old, Togo), (P.7, 33 and P.8, 21 years old, Benin), (P.9, 26 years old, Mali) and (P.10, 29 years old, Afghanistan). The mean of the age for all participants is 26.1.

The second step was to identify errors. To that end, the researchers made use of plausible interpretation for these data from the actual context of the participants. The third phase was the description and/or classification of these errors and the fourth stage was the explanation of them (source and effects including linguistic and non-linguistic factors). Finally, the researchers concluded their analysis (that was revised, edited and supervised by some Arabic Language experts) with the evaluation or the assessment of these errors, suggesting some solutions and treatments for further studies.

\section{Literature Review}

Written work on SLL has been broadly discussed by many linguists who were trying to find reasons explaining how and why SLL commit such errors. Some researchers thought it may be accounted for because of the influence of the first language (L1) on the second (L2) (Guleye, 1980). This motivates others in the field to test the phenomenon against theories including Critical Period Hypothesis (CPH) (Patkowski, 2011) and overgeneralization theory (Chimombo, 2011). Other researchers decided to study the relationship between native speakers and SLL by comparing their interaction to grammatical errors (Magnan, 1981).

The trends of studies on written grammatical errors moved to describe the relationships between different grammatical items. Exploring the relationship between "markednedss" and "permeability" in view of the linguistic theory to L2, one of the conclusions of Munoz-Liceras (2011) is that the difficulty of the different relativized positions is determined by structural principles and not grammatical relations. This kind of correlational studies was broadened to include also the language interference which was investigated later by some linguists who concluded that it is not the sole reason behind non-native speaker's capacity to acquire L2 as some other factors should be taken into consideration like carelessness, unfamiliarity with L2 rules, etc. (Zreg, 2011)

Examining the reaction of the native speakers to the grammatical outputs of SLL, Delamere's 
study in12011 resulted that SLL become either advantageous or preferable to control over their grammatical or lexical contents. In fact, reaction cannot be fully understood without grasping behavior and that is what Marsh(2011) has done when he analyzed the code switching behavior simultaneously practiced by SLL and concluded to the fact that code switching depends on several factors including the speaker's age, level of bilingualism, social role, etc. Since behavior is in a way or another related to the acquisition, Archibald (2011) discussed it in relation to the metrical parameters of L2. One of Archibald's conclusions was that subjects with lower grammatical proficiency do not make fewer stress-placements than those with higher grammatical ones.

Studies in the last three decades began to direct SLL by advising them to shift the type of their writing from mechanical into meaningful one, providing them with the guidelines of American Council on the Teaching Foreign Language (ACTFL)(Moser, 2011). Some researchers believed in the integrity of skills, claiming that each skill completes the function of the other which leads to form the speech (Johnson, 2011) although this claim was objected by Rhee who in 2011 proved that the complexity of the grammatical rule itself makes it almost impossible for the SLL to produce acceptable sentences no matter what integration between language proficiency and language components we have (Rhee, 2011).

Trying to specify which of the four variables (The length of time spent in study in foreign language country, the types of errors committed, L1 of SLL, and his/her experience in Intensive English Program (IEP) if any) might affect SLL writing, results of Smith (2011)'s study outline that those who studied in the foreign countries and took an intensive IEP were highest rated. In fact, linguists normally advise SLL to do some courses in institutions like the one mentioned above, because they feel that such institutions can compensate the lack of acquiring the language where learners might face problems related to usage. Analyzing the difficulties faced by SLL when producing collocations, Lombard (1997) claims that these difficulties may be accounted for because of SLL's nature of distinctive production problems with collocation.

Measuring formal "accentedness" of SLL's pronunciations towards L1, Cesar-Lee (2011) concluded that the duration of the syllable functions as a carrier for the accent of L1 in L2 and associates with the perceived levels of the L2 accentedness. Exploring language attitudes held by native speakers towards SLL, McLendon (2011) concluded to the fact that unlike what we see in pronunciation where good pronunciation is rated significantly higher than weak one, good and weak grammar are almost rated the same.

Some linguists claimed that understanding the characteristics of Arabic may serve as a good means of solving all grammatical problems related to it (Baalbaki, 2001); others tried to find effective treatments for non-native speakers' writing (Ferris, 2002), suggesting contrasting complex rules (Leki, 2002; Stapleton, 2002). Koshik (2002) advocated individual conferences with learners as a means of addressing errors. Sheehan (2011) compared written essays by native speakers and SLL. The purpose was to examine the effects of absence of linguistic features that help in the process of identifying the writer as SLL. The researcher resulted to emphasizing on the fact that grammatical and structural errors were present both 
in indigenous and SLL's work. In fact, what the person produces depends upon what he/she receives. It is for this reason that some linguists think that it will be useful to examine the reasons behind weak output (Al-Hamad, 2003), considering internet as a threat through which interactive Arabic grammar face problems (Nielsoen \& Carlsen, 2003)

It is for this reason actually that linguists decided to examine the variations both in the inter-language and intra-language through ordinary as well as academic writing. Studying common writing errors and variations in the use of non-native language in terms of contrastive analysis, Pastor and Luisa (2003) concluded that the most common errors coincided with the most noticeable variations in the interlanguage created by the Non-native Writers (NNW).

Studying the effects of grammatical and pragmatic errors on non-native speaker's personal impression formation, Kimura (2011) concluded by saying that while grammatical errors have influence on the listener's evaluation, there is no concrete evidence that pragmatic errors have this influence. Examining whether various types of tasks can affect the occurrence and use of recasts in the interaction between native and SLL of language, Lee's results in (2011) showed that there is no such affect to be mentioned neither on the occurrence nor on the use of recasts. Focusing on determiners and V forms and the way how SLL can automatically correct them in their written texts, Lee (2011) concluded by presenting new methods that depend upon how interested our multiple-choice items are. Based on such results, linguists started to think of studying certain languages which they take as samples for their applications. Exploring whether SLL worldwide can understand Chinese websites, the study of $\mathrm{Hu}(2011)$ showed that findings were largely consistent with the text analysis.

Some linguists thought that the problem is not restricted to the learners; rather, it is related to the methodology of understanding Arabic grammar, namely the parsing (analyzing the sentences into forms and then examining the grammatical items of each form in that sentence) part. For that matter, they attempted to improve a parser that functions as a facilitator for this ASL learners, because, according to them, understanding parsing means understanding all grammatical structures that will be used by ASL learner (Bataineh \& Bataineh, 2009). To that end, grammarians started to investigate morphosyntactic issues, trying to find some solutions for them from old Arabic grammar books (Kasher, 2009). Looking at it from a religious perspective, some grammarians thought that examining the motivations of the ASL learners will help identify the best treatment for the way ASL is taught (Bakar et al., 2010). Others thought that translation is a key to understanding grammatical structures (Ordan et al., 2010); analyzing the list of restructuring in Arabic-English including grammatical issues like Noun Phrase (NP), adj. P (Dickins, 2010a) and word recognition (Funder, 2010).

Some grammarians suggested comparing a language and/ or a variety of language to another (Al-Zahre \& Boneh, 2010; Lucas, 2010) as this may help in understanding the distinctive features of two languages including the "discoursal" and "denotative" features of each one of them (Dickins, 2010b). Grammatically speaking, comparisons of this nature will help determine whether one of these languages dominates the other like gulf pidgin Arabic (Bakir, 2010) and/ or influences on the other like Arabic language influence on the Ethio- Semitic 
language known as Tigre (A language spoken by Eritrean a predominantly Muslim population) (Bulakh \& Kogan, 2011). The same thing can be seen when examining the similarities and differences of the plural formation in Nubi and Arabic (Kihm, 2011) which, in turn, may help FLL in acquiring the language; therefore, avoid making mistakes, especially if the two languages are of special importance to the indigenous like Arabic in Israel (Yitzhaki, 2011).

Some claim that unprofessional translation may play a role in committing such mistakes to Arabic texts translated from English for many reasons including the "lack of affixes, ambiguity and acceptability of composite constructions are suggested to hinder in coining an acceptable term." (Ahmad, 2011, Abstract). Others think that the grammatical problems remain with no solutions as a result of globalization which means that we will see more violation in the written Arabic (Daoudi, 2011).

Looking at it from different points of views, Arabic grammarians proposed translating books that discuss grammatical issues (Osman, 2011), while some others objected this idea, claiming that the focus should not only be on grammar books; rather, it should be on the old Arabic grammarians themselves, because this may, according to them, help analyze the methods within the context of the Arabic grammar and its theories (Marogy, 2011). However, some others disagreed with such ideas. They suggested introducing new artificial approaches that may help to enhance Arabic speech recognition by writers as well as speakers (Abu-Zeina et al., 2011)

A new trend led by some researchers who resorted to study the mistakes made by advanced Second Language learners, claiming that this may help to fully understand their written mistakes which, in turn, may help researchers to take safeguards to guarantee that these written grammatical errors will not be committed again by novice learners (Başöz \& Aydın, 2011). Those who disagreed with the above mentioned views thought that it is not enough to analyze the errors of these advanced second language learners. According to them, errors should be classified into major and minor ones so that decision-makers, curriculum designers and other experts in the field can easily understand at which part exactly the problem worsens (Abushihab et al., 2011).

Some suggested understanding the characteristics of a language ( Habib, 2011; Abu-'Abbas et al., 2011) as this procedure can help (if not save) the written Arabic text from being misunderstood which, in turn, may cost ASL learner or even the native speaker a tax like being sent to jail for example (Osman \& Angelelli, 2011). Others exaggerated in describing the importance of the written work (e.g., in newspapers, journals, magazines, etc.) as it may, according to them, play a prominent role in framing the public opinion considering the Egyptian upraising as an example (Hamdy \& Gomaa, 2012).

\section{Analysis of Written Grammatical Errors Committed by ASL learners}

\subsection{Major Word Classes (Open classes)}

\subsubsection{Nouns $(\mathrm{N})$}

\subsubsection{Common Nouns $(\mathrm{CN})$}


It seems that P.7 fails to differentiate nouns $(\mathrm{N})$ from adj. It is for this reason perhaps that we find him replaces N mainly CN with adj. like when he writes: (قو اعد النحويه.) * Rules Grammatical' while the correct sentence should have been written: (قو اعد النحو.) 'Rules of grammar.' This kind of random substitution which we have seen in the sentence of P.7 reflects his lack of knowledge of the characteristics of $\mathrm{N}$ which makes him unable to distinguish them from adj. (al-Anșārī, 1990); therefore, he misuses them. However, his sentence could be correct if we add the definite article: (ال) 'The' to the word: (القواعد ) 'rules', because the adj. which is supposed to modify the $\mathrm{N}$ should agree with all its markers including definite articles, masculine-feminine cases, etc.

The situation is different in the correct sentence (قواعد النحو) as the word (قواعد) 'rules' is the first part of what is known in Arabic grammar as the first part/ component of annexation (المضاف) 'adjunct word added as annexed prefix to another to form annexation.' which should not be preceded by the definite article. However, the second word (النحو) 'grammar' forms the second part/component of annexation and is known in Arabic grammar as (المضاف اليه) 'adjunct word added as annexed suffix to another word to form annexation' which, in turns, has to be noun (al-'Akbarī, 1992).

\subsubsection{Proper Nouns (PN)}

P.7 is not familiar with PN. Moreover, he cannot differentiate between them on the basis of gender. For example, he considers some feminine PN masculine ones; therefore, he uses the Arabic masculine V to go with feminine proper noun as can be seen in his sentences when he writes: (دول العربيه يتحدث) “*Arabic countries speaks' (using the V “speak” in a masculine form since he starts the V in Arabic with "يد"), and (موريتانيا هي الوحيد") 'Mauritania is the only.' (Using the adj. (الوحيد) 'the only' in its present form is not acceptable in Arabic as it is masculine here; therefore, P.7 must add Arabic letter " هـ 'H' so that the correct adj. is (الوحيده) 'The only one'. There is no doubt that P.7 makes a false analogy by assuming that the Arabic masculine word (البلا) 'country' occurs between the subject pronoun (S Pron.) (هي) 'She' and adj. (الوحيد) 'The only'. Note here that even if the S Pron. is (هو) 'he', there will not be any difference to the rule. Notice also that (هي) can remain as it is if we substitute the masculine word (البلد) with the feminine word (الدوله) 'State'.

The written errors of P.10 are different from other participants' as he adds the definite article to PN and this can be seen in his sentence: (في أيام الرمضان) '*During times the Ramadan.' where he should have written: (في أيام رمضان) 'During Ramadan times.' as PN, mainly Arabic months, cannot be preceded by the definite article (الل) 'The' ( al-Anbārī, 1995). This is perhaps due to the fact that P.10 thinks that the rule is the same as the one in his language (Dandy) where one can find some months are preceded by the definite articles. Hence, he makes a wrong analogy with Arabic.

\subsubsection{Verbs (V)}

\subsubsection{Main Verbs (MV)}

In his sentence: (وبدأت أن أمارس الإسلام) “*I began in practice Islam.' P.1 makes an error as he 
is supposed to write: (وبدأت ممارسة الإسلام) I began practicing I slam' or (وبدأت في ممارسة الإسلام) 'I began to practice Islam.' if he wants to write what he means/want to say, because in Arabic (المصدر) 'Infinitive' can be either (مؤوّل) 'Covert' or (صريح) 'Overt.' The former consists of أنحر)

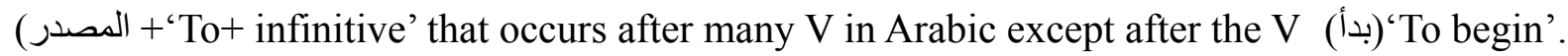
The latter results from combining (To+ infinitive) i.e. (Gerund) and in this kind of infinitive, the writer or the speaker has the right either uses it alone as in the first correct sentence or preceded by the prep. (في) 'In' (al-Azharī, 1996). The researchers believe that it is because of the lack of knowledge of this kind of infinitive in Arabic which cannot be found in many other languages like Albanian (L1 of P.1) and this might be the reason behind committing such errors.

P.1 also fails to apply the rule of Arabic verb tense/aspect system and this can be seen through his double errors in the sentence: (كنت قد أسمع بأن توجد فرصة.) '* I have hear that there a chance.' where the fact is that the sentence should have been written: (كنت قد سمعت بأن هنالك (فرصه (I have heard that there is a chance.' This is, undoubtedly, because of P.1 ignorance of the aspects of $\mathrm{V}$ in Arabic from one hand and also because of not practicing Arabic with native (indigenous) speakers continuously.

When he writes: وقد ترباني و الدي.) ‘*My parents were raised me.', P.8 makes a big mistake. This mistake, however, shows that he does not know how to distinguish V in present tense from those of the past. Such situation can be clearly seen when he adds the letter $(ت)$ ' $T$ ' which (along with three letters more (أ, ن, ') A', 'N' and 'Y') changes the V to present in case if it starts with any of them (al-Siūtī, 1998). In fact, such mistakes show that P.8 is not familiar with the conjugations of the $\mathrm{V}$.

\subsubsection{Adjective (Adj.)}

The sentence: ( درست اللغة العربية خلال السنتين. '* I studied Arabic in the two years.' outlines that P.1 is not familiar with the number-adj. agreement in Arabic which has been broadly explained by Arabic grammarians in response to its ramifications in Arabic grammar (al-Masrī, 1983; al-S'adī, 1983). Prior to any further discussion, it should be known that there are some characteristics of Arabic adj. Unlike English, adj. in Arabic follows N and takes all its case markers (main case markers and/ or sub-case markers). Compare:

Table 1. Adj. order in Arabic and English: Comparison

\begin{tabular}{|l|l|}
\hline Arabic & English \\
\hline رجل طيب (N+Adj) & Good man (Adj+N) \\
\hline
\end{tabular}

In Arabic, if the $\mathrm{N}$ is first person masculine singular (1st. p. m. s.), the adj. should be 1st. p.m.s too. Consider: (أنا رجل طيب.) 'I am a good man.' However, the above mentioned rule applies to first person masculine plural (1st.p.m. pl.), Second Person Masculine plural (2nd. p.m.pl.), Second Person Feminine Plural(2nd. p.f.pl.), Second Person Feminine Singular(2nd. p. f. s.), Second Person Masculine Singular(2nd. p. m .s.), Third Person Feminine Plural(3rd. p.f.pl.), Third Person Feminine Singular( 3rd. p. f. s), Third Person Masculine Plural(3rd. 
p.m.pl.), and Third Person Masculine Singular(3rd. p.m. s.) (ibn-Jinn̄̄, 2008). Compare:

Table 2. Pron.-adj. agreement in Arabic

\begin{tabular}{|c|c|}
\hline Arabic & English \\
\hline رجل طيب & Good man \\
\hline إمر أهّ طيبه & Good woman \\
\hline رجال طييون & Good men. \\
\hline نساء طيبات & Good women. \\
\hline رجلان طيبان & Two good men. \\
\hline إمر أتان طييتان & Two good women. \\
\hline أنتَ طيب & You (male) are good. \\
\hline أنتِ طيبه & You (female) are good. \\
\hline أنتما طيبان /طيبتان & You (dual male / female) are good. \\
\hline أنتم طيبون & You (Plural masculine) are good. \\
\hline أنتن طيبات & You (Plural feminine) are good. \\
\hline
\end{tabular}

Obviously, the form of the adj. in Arabic has changed in the above mentioned sentences according to the $\mathrm{N}$ and / or pron. Unfortunately, this is not the case in English where the adj. "good" remains fixed without any modification in its forms (see Table 2) regardless the $\mathrm{N}$ and/or pron. it accompanies. Thus, P.1 should have written: (خلال السنتين الماضيتين) 'During the past two years.'

In fact, $\mathrm{N}$-adj. agreement should not be taken in isolation. It has to be taken as a part of the whole operation to cover all determiners that might accompany $\mathrm{N}$ which, in turn, might be added to the adj. However, it seems that P. 2 does not know much about these details in the use of Arabic adj.; that is why, he misuses them and this can be obviously seen in his sentence: (*Under national the service.' Unlike Arabic where adj. should agree with $\mathrm{N}$ in all their characteristics, English adj. premodifier occurs immediately after the post determiner, if any, and immediately before the $\mathrm{N}$ post modifier (e.g., four active workers federation). Therefore, the sentence of P.2 should have been written: (تحت الخدمة الوطنيه.) 'Under the national service.' with/out adding the central determiner (C Det.), notably the definite article to the adj. (الوطنيه) in the above mentioned translated sentence.

P.3 shares P.1 and P.2 the same problem in N- adj. agreement in diacritics and in the accusative case. This can be obviously noticed when he writes: (أتمنى ان أكون طالب مجتهـ.*) so to mean 'I wish to be a hardworking student.' as the adj. along with the preceded $\mathrm{N}$ have to be marked with an end vowel sound / / so to be (أتمنى أن اكون طالباً مجتهدأ.). Another example is: I I I studied in Somalia (Local dialect) and England language.' Again, in this sentence there is a feminine N: (اللغة) 'language', which means that the adj. that follows this $\mathrm{N}$ in these two examples should be feminine too (Somali and English accordingly so as to agree with it in number and gender). Moreover, since we have two adj. (Somali and English), the pre-modified N (language) should be dual so that we can achieve the agreement between all sentence elements as Arabic requires that. Hence, the sentence should be written: (درست باللغتين الصومالية والانجليزيه) 'I studied in the two languages: English and Somali.' 
One more example of P.3 errors can be seen in the sentence: (وبعض أماكن التاريخي إسلاميه... * ) for '*...and some places historical Islamic.' while the correct sentence should have been written: (وبعض الاماكن التأريخية الاسلاميه.) '...and some Islamic historical places.' The researchers think that it is due to the lack of knowledge of Arabic grammar, namely adj. order. Nor must we forget also the fact that most of those non-native speakers of Arabic are restricted in their practice of Arabic and do not share their language with native speakers to correct their mistakes before they become errors.

P.3 also makes some other errors regarding comparative adj. like when he writes: (واعتقد أنها (*..... and I think it (Arabic) is easy with other languages.' while the

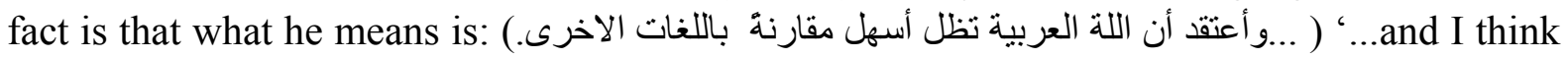
that in compare with other languages, Arabic remains easier.', but he fails to construct it that way and that is what he confirmed later when the researchers asked him about what he wanted to say. P.5 shares many of his colleagues the same difficulty of $\mathrm{N}$-adj. agreement. He cannot, for example, match the $\mathrm{N}$ with the adj. in one of his sentences, especially when he writes: (فصلاته باطل) 'His prayer is no correct.' where the adj. (باطل) 'Incorrect' should match the N (صلاه) and since the former (صلانه) is feminine, the latter has to be feminine too (باطله) as has been clarified in the analysis of P.1 errors.

\subsubsection{Adverb (Adv.)}

\subsubsection{Time Adv.}

It seems that P.5 also is not familiar with T adv. It is for this reason perhaps that he substitutes one for another. This can be seen in his sentence: (إذا مسلم يؤدي إلى الصلاة.) so to mean: 'when a Muslim wants to establish prayer.' where he should have replaced the T adv. (إذأ) 'If' with (عندما) 'when'. Grammatically speaking, the difference between the two adv. in Arabic is that the former should be followed by the perfect $\mathrm{V}$ no matter what aspect it indicates to. In comparison, the latter can be followed by any $\mathrm{V}$ be it in the present or in the perfect form (al-Azharī, 1977). Again, it seems that P.5 does not know much about time adv. in Arabic and the way they are used.

\subsubsection{Adv. N (Manner Adv.)}

P.5 fails to construct the adv. N as can be seen in his sentence when he writes: (سعنعرف معنى*) (He will know the meaning of Quran and prophetic Sunna correct.' where he uses the adj. (صحيح) 'correct' instead of the adv. N ( بشكل صحيح )

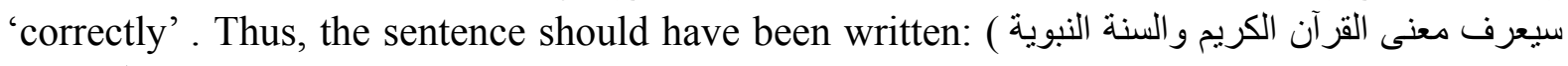

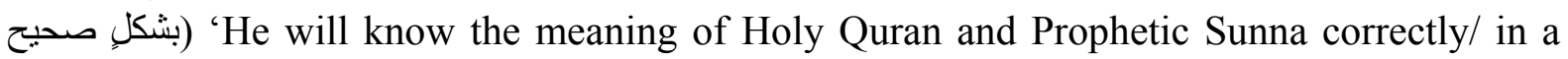
correct way.' This substitution shows that P.5 is not familiar with the use of adv. N.; that is why; he makes a false analogy with adj.

Another similar example made by P.7 when he wrote: (أريد ان أتحدّث هنا قليل.. (*) I want to speak her less....' where he should have written: (أريد ان اتحدث هنا قليلا... ) ' I want to speak here a little .' as the sentence is almost complete and what it lacks is only an adv. $\mathrm{N}$ and not an adj. as P.7 thought. The researchers think that it may be accounted for because of mixing adj. with adv. in Arabic which determines that P.7 should practice what he learned 
with indigenous people (Arabic native speakers), recite the Holy Quran wherein Arabic is well-preserved, and read Arabic novels, poems and stories, especially those that are written in highly standards of Arabic grammar.

\subsection{Minor Word Classes (Closed Classes)}

\subsubsection{Pronoun (Pron.)}

When P.1 writes: (أرسل أبي إلى المدرسة) ‘*My father sent to school.’ (Talking about himself), then, nobody doubts that P.1 fails to use the objective pron. (ني ) ' me' because the Arabic V (يرسل) 'sends' is always followed by something/someone (al-Baghdādī, 1988) and the same thing applies to English. In other words, we (as readers) expect to see an object (His father sent what?). Is it something or somebody? However, if we go over the text, we will find that what he wants to write is probably: (أرسلني أبي إلى المدرسة . My father sent me to the school.'

The researchers believe that it may be accounted for because of the fact that Arabic pron. are more complex than those of other languages, because of their ramifications (ibn-Hishām, 1984). Besides, practicing pron. is the only way that guarantees a better use and usage of them; otherwise, they remain useless and worthless, because pronouns in themselves are meaningless. The same story repeats itself in another sentence of P.1 where we find him writes: (جعل أن أصبح مستقلا....* ) “*...made to be an independent person.' while he should have written: (جعلني أصبح مستقلا ان (

When he writes: (لأننا لا يجد هذه اللغة في المدرسات) 'Because we does not find this language (Arabic) in schools.' P.3 makes a mistake in misusing pron. -V agreement because the sentence has to be singular or plural, not both. Interdisciplinary, the sentence should have been written: (لأنتا لا نجد هذه اللغة في المدارس) 'Because we do not find this language at schools.' as the $\mathrm{S}$ Pron. here is plural while the $\mathrm{V}$ he used is in singular form. Generally speaking, pron. are difficult to teach in Arabic, especially when they are used in Arabic NP which, in turns, can be either annexation or prepositional phrase (Prep. P). It is for this reason that many ASL learners make mistakes in using them.

ASL learners also have problems with Arabic pron., especially those regarding the dual as they have two rules, one for masculine and the other one for feminine. One can see that

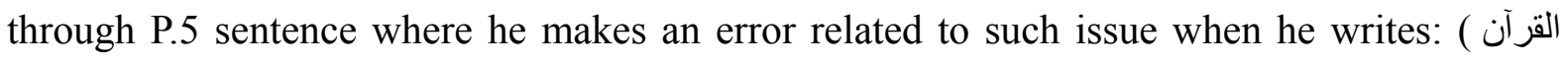

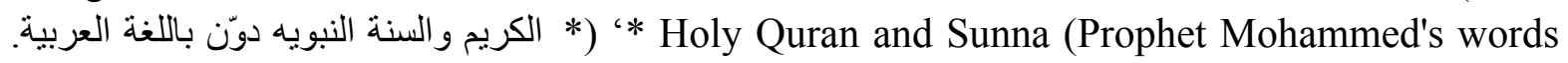
and deeds) was written in Arabic language.' while he should have written: ( القرآن الكريم و السنة 'Holy Quran and Sunna were written in Arabic language.' as there are two S; therefore, the V must go with the dual pron. (al-Hamadhānī, 1985).

\subsubsection{Determiners}

\subsubsection{Central Determiners}

P.1 fails to make correct use of articles mainly indefinite articles where we find him writes for example: (لأدرس في المدرسة أحسن من التي في القرية) 'To study at the school better than that the one of the village.' while the fact is that the word: (المدرسه 'S 'School' here should not be preceded by the definite article (الل) ' the' which also requires some changes like adding the 


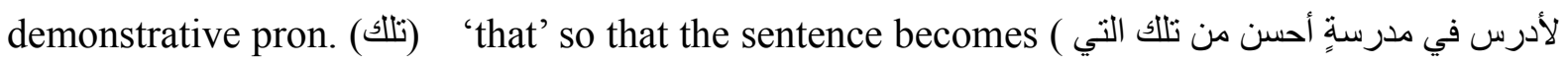
'To study at school better than that of the village.'

P.3 also commits a mistake in the position of the central determiners, mainly, the definite article (الل) 'the' by adding it in a random way to what is known in Arabic grammar as

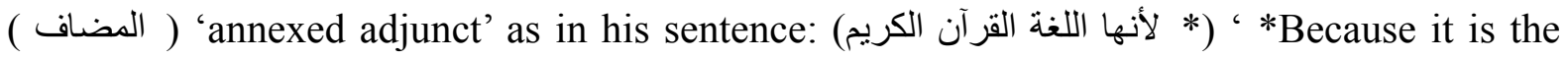
language of the Nobel the Quran.' where it is impossible to use it in this type of structure known as ( شبه الجمله ) 'NP' as (الل) 'the' should be preceded by the annexed adjunct, not the N of the NP sentence. However, without the definite article, the sentence remains correct (لأنها because it is the language of the Nobel Quran.' P.3 also repeats the same

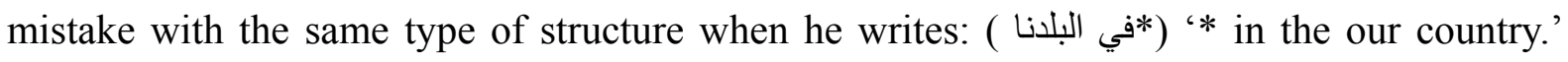
where he should have written: (في بلدنا) 'In our country.'

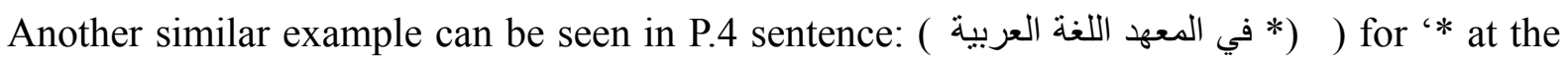

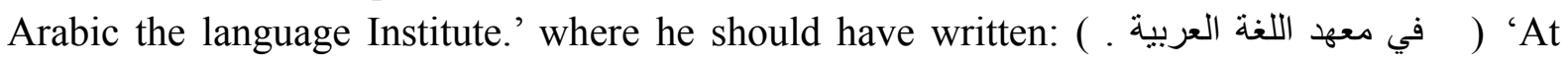
Arabic language Institute.' Again, because it is NP followed by annexation, the definite article should be prefixed to the last two words in the sentence (the $\mathrm{N}$ and adj. that forms the two components of annexation) in Arabic. One more example of P.4 sentences is that when he writes: (اللغة العربية ليست صعبة بل هي جهد و الصبر )*Arabic language is not difficult, but an اللغة العربية لسيت صعبة بل هي مسألة جه ( Arabic language is not difficult, but a matter of effort and patience.' Moreover, in Arabic we have what is known as (واو العطف ) 'wāw of coordination' and we know that what comes after this reflexive wāw should agree with what comes before it in all parsing markers. In clearer terms, if what comes before this wāw is human for example, what comes after it should be human too and the like (al-Jawzī, 1985). Therefore, since it has been preceded by an indefinite word, it has to be followed also by an indefinite word either. This reflects the ignorance of P.4 to use these rules which explains the randomness in the uses of his words.

One more example can be clearly observed in his sentence: (. لديه وقت لدر اسه ووقت لمذاكره ') *He has time study, time memorize lessons, and time relax.' where he should have written: ( لديه وقت للار اسه ووقت للمذاكره ووقت للراحه. ) 'He has time to study, memorize and

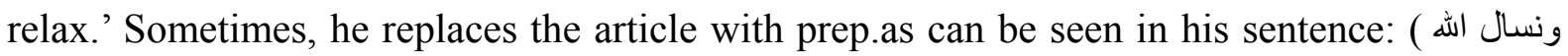
(بصحه) '*we pray to Allah with health.' where he should have substituted the definite article

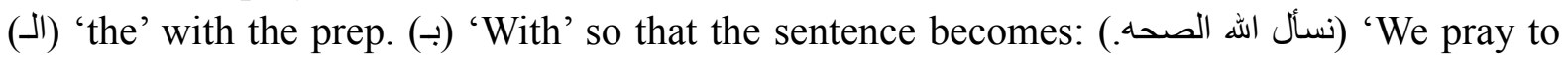
Allah for health.'

أنا الطالب : Adding the definite article randomly is another error committed by P.5 who writes '*I am Chinese the student.' So to mean: (أنا طالب صيني.) 'I am Chinese student.' as we (at least in the present time) are not familiar with his name which means that he should not pre- modify the N (طالب) 'student' unless he had mentioned his name earlier. It seems that P.1 mixes the structure of Arabic determiners, namely (تمييز العدد) ' Number distinctiveness' with the one of his mother tongue (Mandarin) as in his mother tongue; the $\mathrm{N}$ (when it comes after the number) does not change (unlike some languages where some changes are required). Compare: 
Table 3. N with Cardinal Numbers in Chinese, Arabic, English and French: Comparison

\begin{tabular}{|l|l|l|l|}
\hline Mandarin & Arabic & English & French \\
\hline $1 \mathrm{ma}$ & ثصاثة خيول ول حصانان & 1 horse & 1 Cheval \\
\hline $2 \mathrm{ma}$ & 2 horses & 2 Chevals \\
\hline $3 \mathrm{ma}$ & 3 horses & 3 Chevals \\
\hline
\end{tabular}

We can see how in Mandarin the $\mathrm{N}$ that follows cardinal numbers remains fixed (singular), while it changes in Arabic, English and French to indicate plurality. This, undoubtedly, is the reason behind committing this type of errors by this Chinese learner of ASL.

P.5 is not familiar with the usage of Arabic articles where he omits them as can be seen in his sentence when he writes: (*) لذلك مسلم يريد ان يعرف القران الكريم والسنة النبوية) So, Muslim wants to لذلك المسلم يريد ان يعرف : know Holy Quran and prophetic sunna.' while he should have written ( القران الكريم والسنة النبوية) 'So, a/ the Muslim wants to know Holy Quran and prophetic sunna.' Again, it seems that P.5 cannot separate the grammatical system of his L1 from L2 he is studying (Arabic).

When talking about articles also, we find that P.6 almost commits similar mistakes as those of other participants. He is not aware of how to make correct use of the definite articles in Arabic and this can be seen in his sentence: (أنا طالب في الجامعة الملك سعود.) '* I am a student at the KSU the university.' However, in the above mentioned sentence, we find that P.6 misuses the definite article (الـ) ' the' as he places it in the wrong place where it should not be used as the word (الجامعه) ' University' is the first component of annexation; therefore, it should not be pre-modified.

P.7 faces the same difficulty in using articles (omission and/ or addition). While other participants omit them, P.7 adds them to $\mathrm{N}$ where it is almost impossible to use them there. This can be clearly explained through his statement: (بعد الحمد لله وشكره وصلاةً على رسوله. '*After all the praise and thanks are due to Allah and prayers upon His messenger (PBUH).' where he should omit the article(الـ) 'the' in the word (حمد) 'praise' as the words that follow are all pre-modified by indefinite articles. Therefore, according to Arabic grammar, the whole sentence should be defined (each word has to be preceded by a definite article) which means that P.7 sentence has to be either ( بعد الحمد لله والثكر له والصلاة على رسوله. (After )

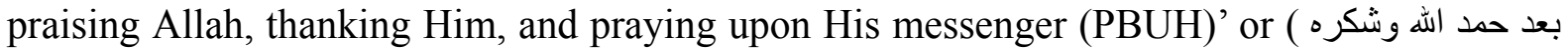
Which of course is better as it seems that P.7 was trying to write it and this can be clearly understood through the context of his paragraphs.

In another example, P.7 adds a definite article where it should not be added as in the sentence: (* '* It is the Quran the language.’ which should be written:

(لغي لغة القران ) 'It is the language of the Quran.' Again, because the word (لغه) '(لغ ) forms the first component of annexation which does not have to be, according to Arabic 
grammar, modified by the definite article (الل) 'the'. What confirms our information about P.7 and his lack of knowledge in using articles is that when he omits the definite article from the

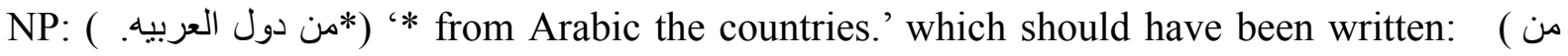
'From the Arabic countries.' as the adj. of the NP should describe the N. Since it (the adj.) is preceded by the definite article, the $\mathrm{N}$ that it describes should agree and be similarly proceeded by a definite article.

It seems that P.9 faces some troubles in using S pron. For example, he omits them as can be seen in his sentence: (أكان في منون الكتب....* ‘...be in the references.' where he should have written: (أكان ذلك في منون الكتب.) '...be it in the references.' as the writer here refers to the

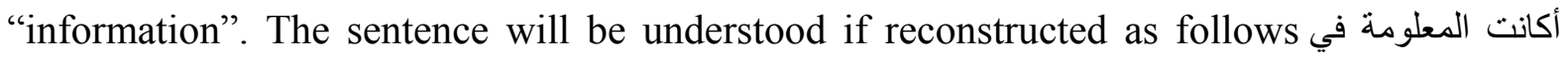
: 'The information was in the sources'.

\subsubsection{Post Determiners}

In the sentence: (مستوى الاول) '* First the level.' we find that P.6 omits the article from the word ( المستوى ) 'level'. However, since we (as readers) know what does he mean by the word: (المستوى) that is, a university level, when he adds the word: (الاول) 'first', we know for sure which level he studies at, but before that when he writes the word: (مستوى) bare from any article, again, we as readers expect him to talk about anything as he opens the door for all possibilities. This is perhaps due to the fact that he does not fully understand the characteristics of the Arabic articles.

Moreover, such mistakes show that he is unable to distinguish the four types of post determiners (Cardinal numbers, ordinal numbers, general ordinals and quantifiers) from each other. Additionally, it seems that he does not know how to differentiate between numbers in ordinal numbers. For example, he writes: (الأول) 'First' and what he means is: (الر ابع) 'Fourth' as he is in the fourth level. Based on such information, learner's error can be determined to be grammatical or lexical. However, when the researchers asked this learner later about what he meant by writing: (الأول) 'the first', it appeared that he has a problem with this type of numbers which means that it is a typical lexical error.

\subsubsection{Prepositions (Prep.)}

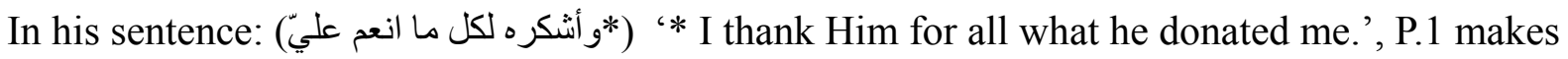
a mistake as he used the prep.(J) 'for' instead of the prep.(على) 'to' that always follows the V ( 'thanks'. It seems that P.1 mixes Arabic concepts like collocation and contextual one with those of English (he studies the two languages at the same time) as Arabic denotations and connotations for example may agree with those of English in some cases, not all (al-Nahawindī, 1985). This similarity and difference between Arabic and English in P.1 sentences can be seen in his errors of prep. including the misuse of the prep. (في) 'in' in his sentence: ( ملات في ألبانيا في عام 1983*) 'I was born in Albania in 1983.' As can be seen in the above translated sentence, the presence of the prep. (في) 'In' is a must in English, but not in Arabic where it is redundant.

Another example can be seen in his sentence: ( البعد من الأسرة) '*staying away in the family.' that should have been written: (البعد عن الاسرة) 'Staying away from the family'; therefore, P.1 
should have substituted the prep. (من) 'In' with the prep. (عن) 'from' which, again, reveals his confusing of distinguishing Arabic collocation from English collocation. One more example can be seen in his sentence: (تخرجت في الثانوية) '*I graduated in high school.' while he should have written: (تخرّجت من الثنانوية العامة) 'I graduated from high school.' as the V (تخرج) 'to graduate' in Arabic has to be followed by the prep. (من) 'From' be it in the present or in the past form, and the same mistake is committed by P.2 who made another mistake related to prep. when he wrote: ( 'نلت شهادة البكالوريوس بكلية التربية. '*I got the B.A. Degree with the Faculty of Education.' whereas the correct sentence should have been written: نلت شهادة (البكالوريوس من كلية التربيه.) 'I got the B.A. Degree from the Faculty of Education.' as the Arabic V (نال) 'to get' has to be followed by the prep. (من) كن) 'From', not the prep. (ب) 'With'.

One more example can be seen in the sentence of P.4 who omits the prep. (ن) 'From' as it can be obviously seen in his sentence: (تخرجت الثنويه) '*I graduated the secondary school.' which has to be written: (تخرجت من الثنانويه) 'I graduated from secondary school.' as the V "graduate" (as has been explained earlier) has to be followed by the prep. (من (م) 'From'. In fact, the problem of P.4 in matters concerning omission and/ or substitution of prepositions continued and this can be seen in another example when he writes : أتيت هنا (المملكة العربية ) ) (أتيت إلى هنا.) instead, as the V (أنى) 'to come' is mostly followed by the prep. (إلى) 'To' as has been discussed earlier.

Another example of P.4 random omission of prep. can also be explained through his sentence:

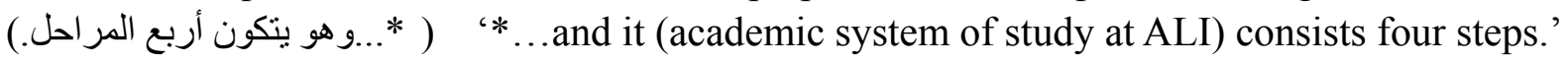
where he omits the prep. (من) 'Of' and this is due to his lack of knowledge in using the prep. generally. As a matter of fact, the researchers think that P.1 and P.2 commit such errors because of their ignorance of Arabic grammar from one hand and the influence of L1 (which plays a pivotal role as the two languages of P1. and P.2 do not include such rules) on the other hand. Consider the sentence of P.1 when he writes: (جئت في السعوديه) ) '* I came in the KSA' where he should have written: ( جئت إلى المملكة العربية السعوديه ) 'I came to the KSA.'

P.2 misuses the Arabic prep. (\lrcorner$)$ 'for' when he uses it in the place where it should not be used, especially if it is pre-modified by verbal phrase as the one he used when he writes: (إستغرق* ( ) ' The teaching took for a year.’ as in Arabic as well as in English, sentences like the one in hand can be understood sans this preposition. Therefore, it should have been written: (إستغرق التدريس سنة) 'The teaching took a year.' and this perhaps is because P.2 (like many other ASL learners) does not practice language with Arab native speakers; that is why, they keep committing such errors.

Like P.1 and P.2, P.3 makes errors in prep., but this time the mistakes are related to the omission of prep.as can be seen in his sentence when he writes: (جئت المملكة*) (ج) I came the Kingdom' where he should have written: (جئت إلى الممكة.) 'I came to the Kingdom.' instead as the V (جاء) 'to come' has to be followed by the prep. (إلى ) 'to'. The researchers believe that the reason behind committing such error is the influence of the Arabic dialect, notably Saudi dialect where P.3 lives as his sentence is accepted in the this dialect which explains why he constructed it that way. Put differently, no Arabic native speaker told him that it is incorrect. In addition to their lack of knowledge of Arabic grammar, the participants make mistakes 
when they speak in dialect which makes it worse, because as time passes by, these ASL learners will find themselves unable to distinguish Modern Standard Arabic (MSA) from dialectal speech.

P.4 makes similar errors in prep. like when he substitutes the prep.(ب) 'of' with the prep.( (\lrcorner$)$ 'for' when he writes: ( لغير الناطقين لها. ) 'For non-native speakers for it (Arabic).'where he should have written: (لغير الناطقين بها ل لغال ) 'For non-native speakers of it.' The researchers believe that it is due to interference from French or English these ASL learners had studied before they learned Arabic. Thus, their system fails in many times to distinguish their latent knowledge of other language with what they are learning. This can be obviously seen in one of P.1 sentences when he replaces the Arabic prep. (في) 'In' with another (من (ن) 'from' when he

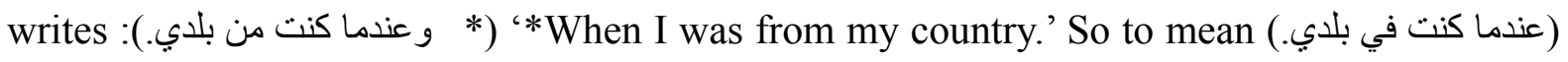
'When I was in my country.'

P.5 makes similar mistakes to those of other participants. Like many of them, he omits the prep. ( في (تخصنص) 'in' that always comes after the Vpecialize' and this can be clearly seen in his sentence: ( أتخصنص عقيدة الاسلاميه ) '*I specialize Islamic belief.' while the correct sentence should have been written: (انخصنص في العقيدة الإسلاميه) 'I specialize in Islamic belief.' It seems that P.5 as well as many of his colleagues has problems related to the uses of Arabic prep.

In his sentence: ( لقألفهم الدين ثم القراءة القرآن) ' To understand the religion (Islam), then the recitation the Quran.' we find that P.5 omits the prep. (\lrcorner$)$ ' to' that should be used here thinking that the word: (القراءه) 'recitation' can be used here also in the same way. However, the use of this prep. in this position exactly is a must. Hence, the sentence should be reconstructed: (لفهم الدين ثم لقراءة القرآن.) To understand the religion and then to be able to recite Quran.' This indicates that P.6 as well as many of his colleagues fails to grasp the Arabic prep. rules.

\section{Conclusions \& Suggestions}

\subsection{Conclusions}

Outcomes of this study show that non-native speakers of Arabic mainly ASL learners make errors in major word classes as well as in minor word classes. Errors of major word classes' include those of $\mathrm{N}$, namely, $\mathrm{CN}$ and proper $\mathrm{N}$. They also make errors in $\mathrm{V}$ mainly MV and the same problem can be seen with adj. Regarding the adv., errors of ASL learners include both time adv. and manner adv. (No errors related to place adv. are marked). ASL learners also have problems regarding pron., notably objective pron.

ASL learners' errors are found in errors relate to use of determiners, namely, articles. It is a question of agreement in determiners and numbers as well. Errors including Dem. and quantifiers have been also observed. Finally, these ASL learners seem to have big problems with Arabic prep. as some of them make a false analogy between these prep. and those in their L1. All in all, the factors behind committing such errors by ASL learners can be classified into two types: Linguistic and non-linguistic factors. 


\subsubsection{Errors Related to Linguistic Factors}

These include interlanguage (L1 interference), general order of difficulty (hierarchy of difficulty) which is applicable to both L1 and L2, the morphemes theory that discusses what is learnt before the other (as some morphemes are more difficult than others), and finally we have intralingual (Target Language source like regular form: within the target language). Examples of intralingual sources include overgeneralization, incomplete applications of rules, and false concepts hypothesized. Nor must we forget to say here that redundancy reduction or false analogy is in a way similar to overgeneralization and one of the causes of it. However, addition and omission are also some types of redundancy.

\subsubsection{Errors related to non-linguistic factors}

These are errors resulting from different things like teaching methodology/ technique, translation(conscious interference), learner's age considering $\mathrm{CPH}$, learning strategy(like the way Arabic grammar is taught in ALI), communication strategy (like when these ASL learners make mistakes and Saudi native speakers agree with them), carelessness(when some ASL learners know the rule, but do not apply it), language creativity( Like using Arabic rules by making a false analogy with those rules in their language), speech reduction(telegraphic style e.g. (سلام) 'Hi' instead of (السلام عليكم ورحمة اله وبر كاته ) 'May peace and mercy of Allah be upon you.'), heavy accent (e.g. using L1 for L2), sociolinguistic situations( like using French as an official language in some African countries where some participants belong.) or a combination of both linguistic and non-linguistic factors.

Additionally, the researchers think that the lack of practice between ASL learners and Saudi native speakers played an important role in turning these mistakes into errors. The seriousness of committing these errors is that in some cases, they may lead to a misunderstanding which, in turns, place ASL learners in awkward situations of being made fun or being misunderstood by others.

\subsection{Suggestion}

\subsubsection{Arabic Language Institute (ALI)}

A common misconception held by most Arabic grammarians is that Arabic grammar cannot be differently presented. Based on the analyses of the corpora collected of the current study, the researchers think that the present method of teaching Arabic to ASL learners is old and has to be changed. Unfortunately, the traditional methods followed in teaching Arabic grammar in ALI as well as in many other Arabic language institutes in the Arab world do not help any more. The researchers recommend authorities responsible for teaching ASL not to spend more time, effort and / or money on methods such as the one used by ASLI at present. The researchers hope that the results of this study should be considered by ALI at KSU which will help their ASL learners to avoid committing such errors in the future.

ALI should also get benefit from the ideas Arabic language experts teaching at Arabic language department. The institute should invite them every now and then to give lectures, revise and/ or edit the institute's curricula and syllabi. It should also consider the audio-visual 
aids and Computer-Assisted Language Teaching (CALT). It should also interact with the creative ideas, suggestions, proposals, comments, notes, etc. of the language experts either those teaching at the institute or those teaching at the Arabic language department in KSU or even those from outside the university. ALI should get benefit from the experiences of other Arabic language centers not only in the Arab world, but worldwide. It should send researchers from the center to visit these centers, share them their experiences and also learn their about their methodologies of teaching.

\subsubsection{ASL Learners}

ASL learners are also advised to try all means that may help to improve their writing like writing long sentences, paragraphs about themselves, or they can describe everything they see and then ask a native speaker to revise what they have written. They can also visit Arabic language department to meet the professors there and practice Arabic with them. ASL learners can also watch Arabic channels including News channels like Al-Jazeera space channel (JSC), al-Arabiya, etc. and then report orthographically whet they watched. They are also recommended to listen to the radio cassettes and then write what they have already listened.

They can also write the words with diacritics and then practice the pronunciations to improve their writing. Alternatively, they can listen to music, notably MSA songs as they have the same effect on non-native speakers as direct pronunciation does (Wicox, 1995). ASL learners are also advised to read Arabic literature including poems, novels, plays, and dramas. More importantly, they have to recite Quran and read also the prophetic narrations as they are written in the highest standards of grammar. ASL learners have to try their best to parse the sentence they read as this will definitely help them to identify how and why this word is written in this/ that form. They can also make use of cards where they can see the picture and describe it. Finally, the researchers recommends for further studies in this field using different methodology and more participants.

\section{References}

Abu-'Abbas, K., Zuraiq, W., \& Abdel-Ghafer, O. (2011). Geminates and Long Consonants in Jordanian Arabic. International Journal Of Linguistics (IJL), 1-17. http://dx.doi.org/10.5296/ijl.v3i1.735.

Abu Shihab, I., El-Omari, A., \& Tobat, M. (2011). An Analysis of Written Grammatical Errors of Arab Learners of English as a Foreign Language at Alzaytoonah Private University of Jordan. European Journal Of Social Science, 543-552.

Abu Zeina, D., Al-Khatib, W., Elshafei, M., \& Al-Muhtaseb, H. (2011). Toward enhanced Arabic speech recognition using part of speech tagging. International Journal Of Speech Technology, 419-426. http://dx.doi.org/10.1007/s10772-011-9121-5.

Ahmad, M. (2011). Constraints on Arabic translations of English technical terms. Babel, 443-451. 
al-'Abkarī, A. (1992). Masāil Khilāfiyah Fı al-Naḥw. Ṭ1. Taḥqīq: Muḥammad Khayr al-Halawānī . Bayrūt: Dār al-Sharq al-'Arabī .

al-Anbārī, ‘. (1995). Asrār al-'Arabiyah. Ṭ1. Tahquĩq al-Duktūr Fakhr Ṣālih Qudārah . Bayrūt : Dār al-Jī .

al-Anșārī, A. (1979). Awḍah al-Masālik Ilā Alfiyat Ibn Malik. Ṭ5. Bayrūt: Dār al-Jīl .

al-Anșārī, Z. (1979). al-Hudūd al-Anīqah Wa al-T'arīfät al-Daqīqah. Ṭ1. Tahquìq al-Duktūr Māzin al-Mubārak . Bayrūt : Dār al-Fikr al-Mu'āṣir.

al-Azharī, K. (1996). Muwașșil al-Ṭullāb Ilā Qawāíd al-l'arāb. T1. Tahquìq al-Duktūr 'Abdul-Karìm Mujāhid . Bayrūt : Mu'assasat al-Risālah .

al-Azharī, M. (1977). al-Zāhir Fi 'Irāb Gharīb Alfāz al-Shāfít. Ṭ1. Taḥqìq al-Duktūr Muhammad Jabr al-Alfi . al-Kuwayt : Wazārat al-Awqāf Wa al-Shu'ūn al-Islāmiyah .

al-Baghdādī, A. (1988). al-'Ușūl FI al-Naḥw. T3. Taḥqīq al-Duktūr 'Abdul-Husayn al-Fattī . Bayrūt: Mu'assat al-Risālah .

Al-Hamad, M. (2011). Morphological and syntactic properties in the acquisition of Arabic as a second language: Implications for the theory of SLA and for language teaching. University of Essex Journal (United Kingdom), England, 2-9. (Publication No. AAT C814774).

al-Hamadhānī, B. (1985). Sharh Ibn 'Aqīl. T2. Tahquiqq: Muḥammad Mihya al-Dìn 'Abdul-Hamìd. Dimishq: Dār al-Fikr .

al-Jawzī, A. (1985). al-Mudhish. Ț2. Taḥqìq al-Duktūr Marwān Qabbānī . Bayrūt: Dār al-Kutub al-'Ilmiyah .

al-Misrī, A. (1983). Risālah Fılsm al-Fāill al-Murād Bih al-Istimrār Fı Jamīa al-Azminah. Ṭ1. Taḥqīq al-Duktūr Muhammad Hasan 'Awwād. 'Ammān: Dār al-Furqān Lil-Nashr Wa al-Tawzī'a .

al-Nahāwindī, A. (1985). al-Lāmāt. T2. Tahquīq: Māzin al-Mubārak . Dimishq: Dār al-Fikr .

al-S'adī, A. (1983). Tahdhīb Kitāb al-Af'āl. Ṭ1. Bayrūt : 'Ālam al-Kutub .

al-Ṣuyūtī, J. (1998). al-Muzhir FI 'Ulūm al-Lughah Wa Anwāîhā. Ṭ1. Tahquīq: Fu'ād 'Alī Manșūr . Bayrūt: al-Dār al-'Ilmiyah .

Al-Zahre, N., \& Boneh, N. (2010). Coreferential Dative Constructions in Syrian Arabic and Modern Hebrew. Brill's Annual Of Afroasiatic Languages \& Linguistics, 248-282. doi:10.1163/187666310X12688137960588.

Archibald, J. (2011). Language learnability and phonology: The acquisition of L2 metrical parameters. University of Toronto Journal (Canada), Canada, 2-8(Publication No. AAT NN78802).

Baalbaki, R. (2001). BĀB AL-FA' $\left[F \bar{A}^{\prime}+\right.$ Subjenctive] in Arabic Grammatical Sources . Arabica, 186.

Bakar, K., Sulaiman, N., \& Rafaai, Z. (2010). Self-Determination Theory And Motivational Orientations Of Arabic Learners: A Principal Component Analysis. GEMA Online Journal Of Language Studies, 71-86. 


\section{MInstitute Macrothink $_{\text {Int }}$}

International Journal of English Language Education

ISSN 2325-0887

2013, Vol. 1, No. 2, Special Issue

Bakir, M. (2010). Notes on the verbal system of Gulf Pidgin Arabic. Journal Of Pidgin \& Creole Languages, 201-228. http://dx.doi.org/10.1075/jpcl.25.2.01bak.

Başöz, T., \& Aydın, S. (2011). An Analysis of the Grammatical Mistakes made by Awarded EFL Writers. E-Journal Of New World Sciences Academy (NWSA), 296-306. (Publication No. AAT3386417).

Bataineh, B., \& Bataineh, E. (2009). An Efficient Recursive Transition Network Parser for Arabic Language. World Congress On Engineering 2009 (Volume 2), 1307-1311.

Bulakh, M., \& Kogan, L. (2011). Arabic influences on Tigre: A preliminary evaluation. Bulletin Of The School Of Oriental \& African Studies, 1-39. http://dx.doi.org/10.1017/S0041977X10000698.

Cesar-Lee, B. (2011). Quantification of accented pronunciation by American-English speakers in French-as-a-foreign language setting. University of Florida Journal , United States -- Florida, 2-8. (Publication No. AAT9945943).

Chimobo, M. (2011). Overgeneralization in Negation: A Comparison of First and Second Language Acquisition. Journal Columbia University Teachers College, United States -- New York, 3-8 (Publication No. AAT 8207307).

Daoudi, A. (2011). Globalisation and e-Arabic: The Emergence of New Language at the Literal and Figurative Levels. Studies In Slavic \& General Linguistics, 3861-3876. (Publication No. AAT3112426).

Delamere, T. (2011). The Role of Stereotyping in Native Speaker Judgements of English as a Second Language Learners' Performance ( Sociolinguistics, Error Analysis, Prejudices). The Florida State University Journal, United States -- Florida, 1-11 (Publication No. AAT 8625770).

Dickins, J. (2010a). Junction in English and Arabic: Syntactic, discoursal and denotative features. Journal Of Pragmatics, 1076-1136. http://dx.doi.org/10.1016/j.pragma.2009.09.003.

Dickins, J. (2010b). List restructuring in Arabic-English translation. Babel, 341-362. http://dx.doi.org/10.1075/babel.56.4.04dic.

Funder, G. (2010). Word Recognition in Arabic as a Foreign Language. Modern Language Journal, 567-581. http://dx.doi.org/10.1111/j.1540-4781.2010.01094x.

Habib, R. (2011). Frequency effects and lexical split in the use of [t] and [s] and [d] and [z] in the Syrian Arabic of Christian rural migrants. Journal Of Historical Linguistics, 77-105. http://dx.doi.org/10.1075/jhl.1.1.04hab.

Hamdy, N., \& Gomaa, E. (2012). Framing the Egyptian Uprising in Arabic Language Newspapers and Social Media. Journal Of Communication, 195-211. http://dx.doi.org/10.1111/j.1460-2466.2012.01637.x. 
Hu, C. (2011). Chinese websites translated into English: How well do they communicate to the international audience. Northwestern University Journal, United States - Illinois , 2-13 (Publication No. AAT 3386417).

Ibn-Hishām, '. (1984). Sharḥ Shudhūr al-Dhahab Fi M'arifat Kalām al-'Arab. Ṭ1. Taḥqīq 'Abdul-Ghanī al-Duqar . Dimishq : al-Sharikah al-Muttahidah Lil-Tawzī’ .

Ibn-Jinnī, A. (1972). Kitāb al-Lam‘a Fì al-'Arabiyah: Taḥqīq: Fā'iz Fāris . al-Kuwayt : Dār al-Kutub al-Thaqāfiyah .

Ibn-Jinnī, A. (2008). al-Khașā'iș. Taḥqīq: Muḥammad 'Ali al-Najjār . Masqaț: al-Maktabah al-'Ilmiyah .

Johnson, R. (2011). The relationship between native listeners' perceptions of personality traits of nonnative speakers and the grammatical errors and phonetic errors in nonnative speakers' speech. The Florida State University Journal, 1-9.( Publication No. AAT 9332306).

Kasher, A. (2009). The Term Ism in Medieval Arabic Grammatical Traditions: A Hyponym of iteself. Journal Of Semitic Studies, 459-474. http://dx.doi.org/10.1093/jss/fgp009.

Kihm, A. (2011). Plural formation in Nubi and Arabic: A comparative study and a word-based approach. BrAnnual Of Afroasiatic Languages \& Linguistics, 1-21. http://dx.doi.org/10.1163/187666311X562431.

Kimura, J. (2011). The effect of grammatical and pragmatic errors on personal impression formation: The case of Japanese learners of English in the United States. California State University Journal, Long Beach, United States -- California, 2-9. (Publication No. AAT 1429308).

Koshik, I. (2002). "Designedly Incomplete Utterances: A Pedagogical Practice for Eliciting Knowledge Displays in Error Correction Sequences." . Study on Language and Social Interaction, 277-309.

Lee, H. (2011). The role of recasts in the interactions of native-speakers of English with Korean English language learners. Iowa State University, United States -- Iowa, 1-10. (Publication No. AAT 1453892).

Lee, J. (2011). Automatic correction of grammatical errors in non-native English text. Massachusetts Institute of Technology, United States -- Massachusetts, 2-7. (Publication No. AAT 0822220).

Leki, I. (2002). Understanding ESL Writers. Portsmouth: New Hampshire: Boynton/Cook.

Lombard, R. (1997). Non-native speaker collocations: A corpus-driven characterization from the writing of native speakers of Mandarin. The University of Texas at Arlington, United States -- Texas, 1-10. (Publication No. AAT 9825559).

Lucas, C. (2010). Negative -š in Palestinian (and Cairene) Arabic: Present and possible past. Brill's Annual Of Afroasiatic Languages \& Linguistics, 165-201. http://dx.doi.org/10.1163/187666310X12688137960623. 


\section{Mll Macrothink}

International Journal of English Language Education ISSN 2325-0887 2013, Vol. 1, No. 2, Special Issue

Marogy, A. (2011). The Legacy of the Kitāb: Sībawayhi's Analytical Methods within the Context of the Arabic Grammatical TheoryBy Ramzi Baalbaki. Journal Of Islamic Studies, 248-252. (Publication No. AAT 9981534).

Marsh, L. (2011). Quede Adentrosale/ It Comes from inside: Code-Switching in Dominican Household in New York City. New York University Journal, United States -- New York., 2-13. (Publication No. AAT 8720131).

McLendon, M. (2011). Language attitudes and foreign accent: A study of Russians' perceptions of non-native speakers. . The University of Texas Journal at Austin, United States -- Texas, 2-11. (Publication No. AAT 9956888).

Moser, B. (2011). Advanced writing in German as a foreign language: An analysis of the linguistic and rhetorical features of successful compositions. Georgetown University, United States -- District of Columbia, 3-14. (Publication No. AAT 9306088).

Munoz-Liceras, J. (2011). Markedness, Contrastive Analysis and the Acquisition of Spanish Syntax by English Speakers . University of Toronto (Canada), Canada, 3-7. (Publication No. AAT NK59858).

Nielsen, H., \& Carlsen, M. (2003). Interactive Arabic Grammar on the Internet: Problems and Solutions. Computer Assisted Language Learning, 95. (Publication No. AAT 8128024).

Ordan, N., Hershberg, N., \& Shlesinger, M. (2010). Translational conflicts between cognate languages: Arabic into Hebrew as case in point8. Corpus Linguistics \& Linguistic Theory, 217-239. http://dx.doi.org/10.1515/CLLT.2010.00.

Osman, G. (2011). Translation and interpreting in the Arabic of the Middle Ages: lessons in contextualization. International Journal Of The Sociology Of Language, 107-125. http://dx.doi.org/10.1515/IJSL.2011.005.

Osman, G., \& Angelelli, C. (2011). “A crime in another language?" revisited: Arabic-centered discourse in the Yousry case. Translation \& Interpreting Studies: The Journal Of The American Translation \& Interpreting Studies Association, 1-23. http://dx.doi.org/10.1075/tis.6.1.01osm.

Patkowski, M. (2011). The Sensitive Period for the Acquisition of Syntax in a Secondary Language . New York University, United States -- New York , 3-9. (Publication No. AAT 8027473).

Rhee, M. (2011). Act and fact in teaching the Korean language: Honorifics in a business setting. The Journal of Language for International Business, 2-8. (Document ID: 879967).

Sheehan, M. (2011). Holistic grading of essays written by native and non-native writers by instructors and independent raters: A comparative study . University of Rhode Island, United States -- Rhode Island, 3-6. (Publication No. AAT 3053122). 


\section{Macrothink \\ International Journal of English Language Education ISSN 2325-0887 \\ 2013, Vol. 1, No. 2, Special Issue}

Smith, E. (2011). Four variables that influence the writing proficiency of nonnative speakers of English in regular college classes. The Claremont Graduate University, United States -California, 1-5. (Publication No. AAT 9703813).

Stapleton, P. (2002). "Critiquing Voice as a Viable Pedagogical Tool in L2 Writing: Returning the Spotlight to Ideas." . Journal of Second Language Writing, 177-190.

Yitzhaki, D. (2011). Attitudes to Arabic language policies in Israel: Evidence from a survey study. Language Problems \& Language Planning, 95-116. ( Publication No. AAT9544866).

Zreg, M. (2011). Identification of Specific Arabic Language Interference Problems and their Effect on the Learning of English Structure. University of Kansas Journal, United States -Kansas, 2-9. (Publication No. AAT8317956) .

\section{List of Abbreviations}

Adj. $=$ Adj

$\operatorname{Adv} .=A d v$.

$\mathrm{ALI}=$ Arabic Language Institute.

$\mathrm{ASL}=$ Arabic as Second Language.

$\mathrm{KSA}=$ Kingdom of Saudi Arabia.

KSU= King Saud University.

$\mathrm{L} 1=$ Mother Tongue .

L2= Second/ Foreign Language.

$\mathrm{N}=$ Noun.

P. = A Participant.

Prep. $=$ Preposition $(\mathrm{s})$

Pron. $=$ Pronoun $(\mathrm{s})$.

SLL $=$ Second Language Learner(s).

\section{Copyright Disclaimer}

Copyright reserved by the author(s).

This article is an open-access article distributed under the terms and conditions of the Creative Commons Attribution license (http://creativecommons.org/licenses/by/3.0/). 